\title{
An update on the pathophysiology of idiopathic intracranial hypertension alias pseudotumor cerebri
}

\section{İdiyopatik intrakraniyal bipertansiyonun -diğer adıyla psödotümör serebrinin- patofizyolojisi üzerine bir güncelleme}

\author{
Betül BAYKAN, Esme EKIZOĞLU, Güneş ALTIOKKA UZUN
}

\begin{abstract}
Summary
Idiopathic intracranial hypertension (IIH) is a syndrome characterized by increased intracranial pressure of unknown cause, leading to severe headache, papilledema and visual disturbances. Its former name, pseudotumor cerebri, has gained popularity recently. The strongest and most consistent risk factors of IIH are obesity and female gender. Infrequently, IIH may present in the absence of papilledema showing a headache profile similar to chronic daily headache with migrainous features. There have been several proposed mechanisms to explain the etiology of this disorder associated with various clinical conditions. In recent years, some inflammatory factors, natriuretic peptides and aquaporins have been proposed as possible contributors of the pathogenesis. On the other hand, some investigators have reported that bilateral transverse sinus stenosis is seen in the majority of IIH patients; therefore, dural sinus stent placement is used in some patients. No single theory has been able to provide a comprehensive answer, and there is no consensus about the exact cause of IIH. The aim of this review was to discuss the new insights on the mysterious pathogenesis of IIH.
\end{abstract}

Key words: Idiopathic intracranial hypertension; pseudotumor cerebri; transverse sinus stenosis.

\begin{abstract}
Özet
İdiyopatik intrakraniyal hipertansiyon (İIH) şiddetli başağrısı, papilödem ve görme bozukluklarına yol açan, nedeni bilinmeyen intrakraniyal basınç artı̧̧ı ile karakterize bir sendromdur. Eskiden kullanılan psödotümör serebri tanımı son yıllarda yeniden gündeme gelmiştir. İdiyopatik intrakraniyal hipertansiyon için en tutarlı ve en güçlü risk faktörleri obezite ve kadın cinsiyettir. Nadiren İİH'de papilödem görülmeyip, başağrısı migrenöz özellikler taşıyan kronik günlük başă̆rısı profili gösterebilir. Farklı klinik durumlarla birlikteliği görülen bu durumun etiyolojisini açıklamaya yönelik çeşitli mekanizmalar öne sürülmüştür. Son yıllarda, enflamatuvar etmenler, natriüretik peptitler ve akuaporinlerin pathogeneze katkı olasilıları üzerinde durulmaktadır. Öte yandan bazı araştırıc1lar, İİH hastalarının çoğunda iki yanlı transvers sinüs darlğ̆ı görüldüğünü bildirmiş, bu nedenle de bazı hastalarda dural sinüslere stent yerleştirilmiştir. Görüldüğ̈ gibi tek bir kuram bu sendromla ilgili soruları açıklamaya yetmemektedir ve İİH'nin kesin nedeni üzerinde görüş birliği sağlanamamıştır. Bu derlemenin amacı, İİH'nin gizemli patogenezi üzerine yeni gelişen görüşleri tartışmaktır. Anahtar sözcükler: İdiyopatik intrakraniyal hipertansiyon; psödotümör serebri; transvers sinüs stenozu.
\end{abstract}

\section{Introduction}

Idiopathic intracranial hypertension (IIH) is a wellknown but under-investigated clinical entity with an unsolved pathophysiologic background; hence its diagnosis and optimal management usually cre- ates problems for clinicians. The terms "pseudotumor cerebri" and "benign intracranial hypertension" were originally applied to patients with increased intracranial pressure (ICP) in whom no tumor was found and whose course was believed to be benign.

Department of Neurology, Istanbul University Istanbul Faculty of Medicine, Istanbul, Turkey İstanbul Üniversitesi İstanbul Tıp Fakültesi, Nöroloji Anabilim Dalı, İstanbul

Submitted (Başvuru tarihi) 04.03.2014 Accepted after revision (Düzeltme sonrası kabul tarihi) 29.05.2014

Correspondence (IIletişim): Dr. Esme Ekizoğlu. İstanbul Üniversitesi İstanbul Tıp Fakültesi, Nöroloji Anabilim Dalı, Çapa, İstanbul, Türkiye.

Tel: +90 - 212 - 4142000 / 31291 e-mail (e-posta): esmeekizoglu@yahoo.com 
However, this clinical picture is neither always benign nor related to a false tumor and therefore its terminology was changed to "idiopathic intracranial hypertension". ${ }^{[1,2]}$ On the other hand, Friedman et al. have recently proposed that the umbrella term "pseudotumor cerebri" should be used for the patients having ICP with unclear etiology or secondary causes such as medications and other medical conditions. ${ }^{[3]}$ The pathogenesis of raised ICP in these conditions remains still unclear. Several pathophysiologic mechanisms regulating cerebrospinal fluid (CSF) pressure have been postulated. In this review, we aim to discuss the emerging new insights on the pathogenesis of IIH.

\section{Epidemiology- clinical features}

The incidence of IIH is $1-2$ in 100000 population but increases to 19 in 100000 obese women of childbearing age. ${ }^{[4,5]}$ There is a clear predilection for women over men ranging from 4,3:1 to $15: 1$ in the literature. ${ }^{[4-7]} \mathrm{IIH}$ may also occur in children, but obesity and female predominance appear to be less common in prepubertal children with IIH. ${ }^{[8]}$

IIH is characterized by ICP leading to headache, papilledema, visual symptoms and signs, without any lateralizing findings in the neurological examination, and normal CSF findings. ${ }^{[9]}$ The headache attributed to IIH should be progressive with at least one of the following characteristics; daily occurrence, diffuse and/or constant (non-pulsating) and aggravated by coughing or straining. ${ }^{[10]}$ In our previous study, we showed the presence of allodynia accompanying headache in half of the patients with $\mathrm{IIH}$, typically in unilateral V1 distribution. These patients with allodynia had mostly headache features similar to migraine, whereas patients without allodynia reported more frequently non-migrainous headache. Only 12 of these 46 patients with IIH had previous migraine diagnosis and 7 of the remaining patients were diagnosed previously with tension type headache. Moreover, our study supported the fact that patients with IIH often relapse or continue experiencing headaches, despite the apparent normalization of their ICP. ${ }^{[11]}$

Infrequently, IIH may present in the absence of papilledema ${ }^{[12-14]}$ and the patients may experience a headache profile similar to chronic daily headache with migrainous features, responding to spesific antimigraine agents as well. ${ }^{[15]}$ In a recent study, these patients without papilledema had lower opening pressure when compared with those with papilledema and visual acuities were similar between two groups. ${ }^{[16]}$

There are some intriguing clinical differences regarding visual outcome in older patients and men with IIH. ${ }^{[17-19]}$ Patients older than 50 years had fewer complaints of headache and visual disturbances ${ }^{[19]}$ and the visual prognosis was found to be better in the elderly. ${ }^{[18]}$ On the other hand, it was reported that men with IIH need to be followed up more closely regarding visual function because they may not experience or report other IIH symptoms like headache alarming the clinician. ${ }^{[20]}$ In children with $\mathrm{IIH}$, headache is the most common symptom, but they also have a higher incidence of ocular motility dysfunction and cranial nerve deficits are more common in comparison to adult patients. ${ }^{[21]}$

According to recent studies, there is also some evidence that the patients with IIH have olfactory bulb volume changes and decreased olfaction accompanying other conventional symptoms of IIH. ${ }^{[22,23]}$

The diagnostic characteristics of this syndrome were first defined by Dandy in $1937^{[24]}$ and were later formulated as "Modified Dandy Criteria" by Smith in $1985 .{ }^{[25]}$ These criteria were revised owing to the developments in the neuro-imaging. Magnetic resonance imaging (MRI) or contrast-enhanced computerized tomography (CT) were recommended for typical IIH patients, but MRI and MR venography (MRV) were used for all others. ${ }^{[26]}$ Friedman et al., who preferred to call the syndrome pseudotumor cerebri, proposed recently updated criteria for the diagnosis which required: Papilledema, normal neurologic examination except for intracranial nerve abnormalities, neuroimaging findings including normal brain parenchyma and no abnormal meningeal enhancement on MRI for typical patients and MRI and MRV for others (contrast-enhanced CT if MRI is unavailable or contraindicated), normal CSF composition and elevated lumbar puncture opening pressure ( $\geq 250 \mathrm{~mm}$ CSF in adults and $\geq 280 \mathrm{~mm} \mathrm{CSF}$ in children). ${ }^{[3]}$ They also proposed that in the absence of papilledema, the diagnosis would be suggested if at 
least 3 of the following neuroimaging features were present additionally: 1) Empty sella, 2) Flattening of the posterior aspect of the globe, 3) Distention of the perioptic subarachnoid space with or without a tortuous optic nerve, 4) Transverse venous sinus stenosis. ${ }^{[3]}$

\section{Pathophysiology}

Although recognized for more than a century, the pathogenesis of IIH remains still unclear. There are several proposed mechanisms such as parenchymal edema, increased cerebral blood volume, excessive CSF production; venous outflow obstruction and compromised CSF resorption. ${ }^{[27]}$ In recent years, possible contribution of inflammatory factors has also been proposed. ${ }^{[28]}$ No single theory has been able to provide a comprehensive answer and there is no consensus about the exact cause of IIH.

Says and Joynt reported microscopic evidence of intracellular and extracellular edema ${ }^{[29]}$ and later some MR studies also showed increased water content of the brain ${ }^{[30]}$ and water diffusion in subcortical white matter ${ }^{[31]}$ providing an indirect evidence of brain edema without further confirmation. Dandy first hypothesized that the volume of either cerebral blood or CSF might be increased in this condition. ${ }^{\text {[24] }}$ Some later reports ${ }^{[32,33]}$ supported the presence of increased cerebral blood volume in IIH using intracarotid tracer injection in anesthetized IIH patients. An excessive CSF production has also been proposed but the normal or decreased ventricular size found in IIH patients suggests that there is no increased CSF production in most of the patients. [27] Some studies also demonstrated an abnormally increased outflow resistance, indicating a potential defect through arachnoid granulations. ${ }^{[34-37]}$

\section{Obesity and chronic inflammation}

The strongest and most consistent risk factors of IIH are obesity and female gender; like women, men with IIH are also typically obese. ${ }^{[20]}$ Daniels et al. demonstrated a correlation between body mass index (BMI) and the risk of $\mathrm{IIH}^{[38]}$ and increased weight was found to be associated with the recurrence of the disease. ${ }^{[39]}$ Furthermore, severely obese IIH patients had more advanced papilledema and more severe visual loss than less obese patients ${ }^{[40]}$ and even a relatively small weight reduction has improved vision according to some studies. ${ }^{[41]}$
Although obesity is clearly associated with IIH, its pathophysiologic mechanism remains undetermined. It has been suggested that obesity causing increased intraabdominal pressure could lead to reduced cerebral venous drainage. ${ }^{[42]}$ Very recently, chronic inflammation associated with obesity which can lead to a pro-thrombotic state has been proposed as one of the possible etiological factors in the development of IIH. ${ }^{[28]}$ Obesity is recognized as a proinflammatory state and is associated with increased expression of a number of adipokines and various cytokines including leptin and interleukins, macrophage chemotactic protein-1 (MCP-1/ CCL2) and plasminogen activator inhibitor-1 (PAI1). Leptin levels are found to fluctuate during an inflammatory state. ${ }^{[43]}$ In a study by Lampl et al., significantly elevated serum leptin levels in obese patients with IIH were found compared with both obese and non-obese controls. ${ }^{[44]}$ Ball et al. reported that significantly higher levels of CSF leptin were present in IIH patients after correcting for BMI and age, but no significant difference was found in serum leptin between the groups. ${ }^{[45]}$ However Dhungana et al. found no significant difference in CSF leptin of eight IIH patients compared with eight controls (albeit without adjusting for BMI). ${ }^{[46]}$ In a recent study which analyzed the concentrations of 14 different cytokines, IIH was found to be associated with elevated levels of IL-17 and IL-2 in the CSF, supporting the presence of an intrathecal inflammatory process. ${ }^{[4]]}$

Adipose tissue is considered as an actively secreting endocrine tissue. ${ }^{[48]}$ One of the long-standing hypotheses for the pathogenesis of IIH is abnormal vitamin A metabolism. Some studies showed that the retinol level is elevated in CSF of patients with IIH. ${ }^{[49,50]}$ Adipose tissue-derived retinol binding protein is released from adipose tissue as the name implicates and acts as a modulator of insulin sensitivity. [49] Given the strong predilection of IIH for obese young women, larger studies are warranted to elucidate the true role of CSF vs. serum leptin and other adipose tissue-produced cytokines and molecules in the pathophysiology of IIH.

\section{Sex hormonal dysfunction}

Sex hormones have been suspected as having a role in the pathogenesis of IIH because of the preferen- 
tial occurrence of the disorder among post-pubertal, pre-menopausal women, ${ }^{[20]}$ and the absence of a gender preference before puberty. ${ }^{[51]}$ Despite some conflicting reports, ${ }^{[52,53]}$ the role of a sex hormone disturbance in the pathogenesis cannot be entirely ruled out. Many patients give a history of menstrual irregularities and there have been case reports linking IIH to the use of oral contraceptive pills and also polycystic ovarian disease. ${ }^{[54,55]}$ Polycystic ovarian syndrome (PCOS) is a chronic endocrine condition leading to menstrual and ovulatory dysfunction, linked to obesity, high levels of serum leptin and low grade inflammation. The first line treatment is weight reduction which is also valuable in the management of IIH. The prevalence of PCOS in women referred because of IIH is reported to be $39 \%{ }^{[55]}$ to $57 \%$. ${ }^{[54]}$ Thus the ratio is 5 to 8 times greater than the $7 \%$ prevalence of PCOS in the general unselected population. ${ }^{[56]}$ Furthermore, IIH was found to be particularly associated with gynecoid type obesity rather than with abdominal obesity, which also emphasizes the role of sex hormonal dysfunction in the pathogenesis of IIH. ${ }^{[57]}$

\section{Natriuretic peptides}

Another important recent study by Skau et al. evaluated the natriuretic peptide system as a possible cause of disturbed ICP autoregulation in 40 patients with IIH. ${ }^{[58]}$ This natriuretic peptide system which is also expressed in the central nervous system comprises a family of structurally related neuro-peptides (NP) with antagonizing properties against the renin-angiotensin-aldosterone system. The more well-known atrial natriuretic peptide (ANP) and Btype natriuretic peptide (BNP) are released primarily from cardiomyocytes in response to increased wall-tension and promote natriuresis and diuresis. In contrast, C-type natriuretic peptide (CNP) is released from various tissues including endothelial cells, and acts as a paracrine relaxant of vascular tone. Increased concentrations of NPs in CSF have been shown in intracranial hypertension, i.e. subarachnoidal hemorrhage. Moreover, intraventricular administration of ANP reduces elevated ICP and CSF production in rodent models. Since two of these three NP receptors, NPR-A and NPR-C, have been located to the choroid plexus where two-thirds of the total CSF production is generated, it has been suggested that NPs may be involved in the regula- tion of liquor dynamics. Plasma levels of proCNP were significantly lower in IIH patients and levels of proBNP were significantly lower in IIH patients compared with those of controls. More interestingly, the plasma concentrations of these neuropeptides are inversely associated with BMI and may increase during weight-loss. ${ }^{[58]}$

Considering the association between peripheral NP production and obesity, and the proposed ICP regulatory actions of NPs, it is tempting to hypothesize that there is a link between IIH and NP concentrations.

\section{Aquaporins and anti-neuronal antibodies}

The discovery of the aquaporin (AQP) family of membrane water channels has provided new insights into the pathophysiology of brain water homeostasis. AQPs are a large family of water channels, expressed in plasma membrane of many cell types in the CNS and eye. Aquaporin 1 (AQP1) is mainly detected on epithelial cells in the choroid plexus, responsible for water secretion into the subarachnoid space. ${ }^{[59]}$ Medications could used for IIH downregulate $\mathrm{AQP} 1^{[60]}$ and several drugs such as retinoids and steroids have been shown to induce AQP1 expression suggesting the causative role of AQP1 in the pathogenesis of drug-induced IIH. ${ }^{[61,62]}$ Furthermore, AQP1 was found to be associated with weight gain in an animal model. ${ }^{[63]}$ Aquaporin-4 (AQP4) is another one of the major water channels in the brain. It has been presumed to play an important functional role in the transport of water in and out of the brain, due to its wide distribution within the CNS, including the choroid plexus and ependymal cells of the ventricles and its critical localization in astrocytic foot processes along the blood-brain barrier and brain-CSF interface. ${ }^{[64]}$ Many studies of transgenic mice with a complete deficiency or altered expression of AQP4 suggest a prominent role for AQP4 in cerebral water transport. ${ }^{[65,66]}$ AQP4 seems to play a significant role in the development of cytotoxic edema and the absorption of excess brain water resulting from vasogenic edema. However, these important preclinical results have not been translated to human clinical diseases, except the association with neuromyelitis optica. ${ }^{[67]}$ We and others could not demonstrate any association of AQP4 with IIH. ${ }^{[68,69]}$ Other studies 


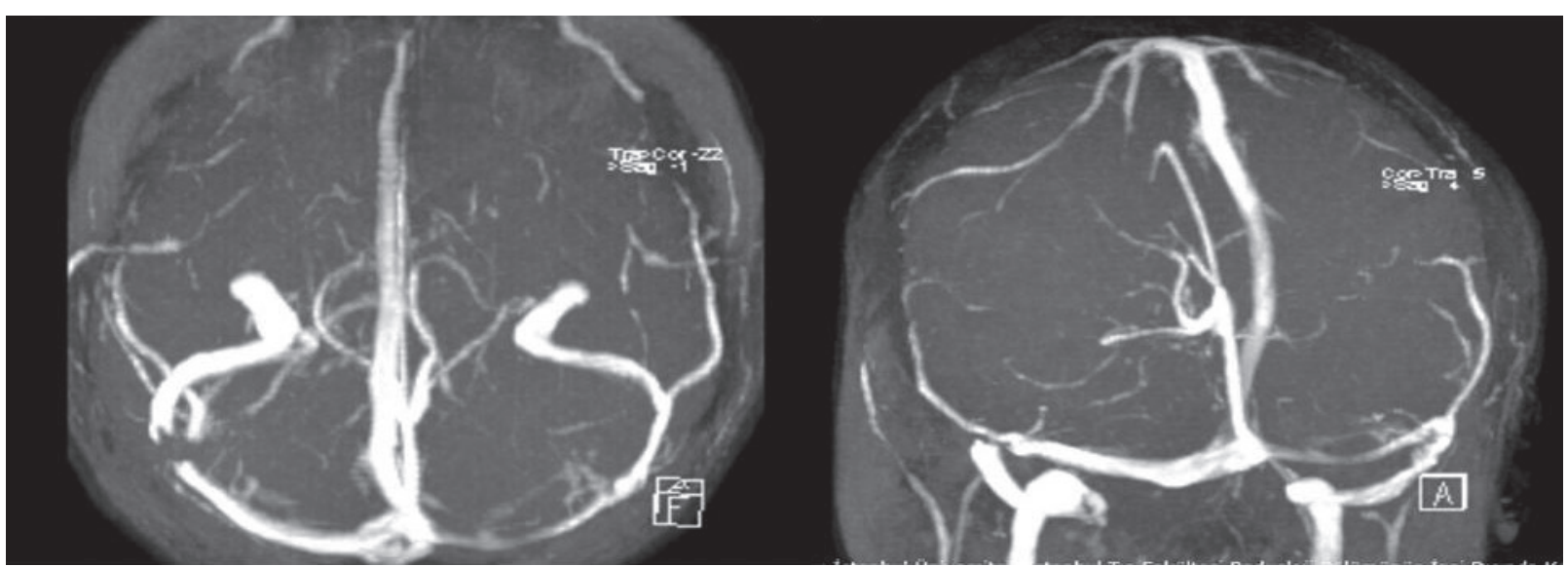

Figure 1. Standard MR-Venograghy of a patient diagnosed with IIH demonstrating prominent stenosis on the left transverse sinus and irregularities on the right transverse sinus.

are needed to elucidate the role of other Aquaporins and the water pump system.

Furthermore, we identified different IgG binding patterns (i.e. anti-neuronal antibodies) in the sera of several IIH patients in rates comparable to those of encephalitis patients. ${ }^{[69]}$ Our results might suggest that inflammatory mechanisms are in play at least in some IIH patients and thus further investigation of potential neuronal target autoantigens is warranted to fully understand the pathophysiology of IIH.

\section{New insights from neuro-imaging and bilateral transverse sinus stenosis story}

Diagnosis of IIH is based on normal neuroimaging of the brain, including MRV. However there is current evidence that some patients with IIH have bilateral transverse sinus stenosis (BTSS). ${ }^{[70]}$ The transverse sinuses are well-known to be asymmetric in most individuals and an unilateral hypoplastic transverse sinus is considered a "normal variant" without any reported changes of ICP. MRV with an auto-triggered elliptic centric-ordered sequence demonstrated variable degrees of cerebral venous stenosis in most of the IIH cases compared with normal controls. ${ }^{[71]}$ Furthermore, BTSS was found to predict the presence of increased ICP in patients diagnosed with migraine or chronic tension-type headache. ${ }^{[72,73]}$ Thus, it has been proposed that the presence of transverse sinus stenosis may support the diagnosis of IIH without papilledema, as mentioned above. ${ }^{[3]}$ But, BTSS is uncommonly encountered in clinical practice, probably depending on the imaging technique and experience of the neuroradiologist (Figure 1).
There is a debate on whether such a stenosis is the cause or effect of IIH. Some authors argued that the venous sinus theory could not explain the female predominance of IIH in adults. ${ }^{[74]}$ Moreover, the clinical course, including visual field loss, was not correlated with the degree of transverse sinus stenosis. ${ }^{[70]}$ It has also been suggested that such narrowing is secondary to compression of the sinuses by the raised ICP causing outflow obstruction, which results in further venous hypertension, then decreases CSF absorption and causes further ICP. ${ }^{[75,76]}$ Furthermore, some anatomic studies suggested that these stenoses occur due to the presence of trabeculae, septae or hypertrophied granulations in the transverse sinuses. ${ }^{[77,78]}$ A positive feedback mechanism has also been proposed suggesting that venous hypertension leads to further increased ICP, independently of the initial cause of focal stenosis. ${ }^{[79]}$

Venous sinus stenting was therefore used in some patients with conflicting results. Some investigators found that tranverse sinus stent placement is effective in IIH patients and suggested it could be a new treatment option in this group. ${ }^{[00-82]} \mathrm{A}$ review of literature including $143 \mathrm{IIH}$ patients treated with venous sinus stenting revealed that most of the patients had improvement of headache, papilledema or visual acuity after this procedure, ${ }^{[79]}$ even unilateral stenting was found to be effective to reduce pressure gradients in BTSS. ${ }^{[83]}$ On the other hand, Kumpe et al. detected a new narrowing above the stent in 3 of 15 patients with a follow up by venography or venous pressure measurements. ${ }^{[82]}$ Rohr et al. reported restenosis in 3 cases associated with recurrence of 
symptoms and suggested that increased ICP was the primary problem leading to venous compression. They proposed to do MRV before and after maximal CSF diversion in patients with suspected IIH, to distinguish reversible and fixed stenosis of transverse sinuses aiding in the choice of therapy-ventriculoperitoneal shunt surgery versus stent placement. ${ }^{[84]}$ In another study Rohr et al. found volume changes in the entire dural sinus system in IIH patients becoming normal after treatment and they suggested that ICP changes are linked to volume decrease of the whole sinus tree. ${ }^{[85]}$ Other studies have demonstrated improvement in these stenoses after CSF removal. ${ }^{[86,87]}$ It has also been postulated that following a relatively minor increase of ICP, a possible abnormal flexibility of transverses sinuses in this group could lead to a significant sinus stenosis and increase venous pressure unlike in normal individuals. ${ }^{[88-90]}$ Some authors concluded that medical treatment failure should be considered to decide for stenting procedure instead of the radiographic severity of the stenosis. ${ }^{[0,91]}$

On the other hand, anatomic variants or flow artifacts of venous sinuses often make MRV interpretation difficult. Flow abnormalities in a single transverse sinus (TS) can occur in up to $30 \%$ of normal individuals. ${ }^{[92]}$ It is also worth emphasizing that one-third of the patients with BTSS had normal CSF pressure, ${ }^{[73]}$ suggesting that BTSS is only one of the contributing factors involved in IIH. Moreover BTSS, as revealed by MRV, persists in patients with IIH after normalization of CSF pressure, showing the lack of a direct relationship between the caliber of TS and CSF pressure. ${ }^{[93]}$

Thus, many findings suggest that venous flow disturbances in IIH are most probably the consequence of CSF hypertension, but not its cause. ${ }^{[74]}$ However, transverse sinus stenting may be evaluated as an effective treatment option by breaking the aforementioned abnormal positive biofeedback cycle, in selected patients having medically refractory IIH.

\section{Secondary causes, underlying factors}

ICP may be secondary to several causes such as venous sinus thrombosis, medical conditions and drugs. Some investigators proposed that increased venous pressure might be the key factor in the devel- opment of IIH because it is the unifying mechanism for all of the benign tumor-like syndromes. ${ }^{[94]}$ Cerebral venous thrombosis has been found in $11.4 \%$ of patients who were presumed to have IIH. ${ }^{[95]}$

IIH has been associated with many etiologies such as exposition to a number of drugs (vitamin A, growth hormone, steroids, minocycline and tetracycline, sulphasalazine, etc...), ${ }^{[96-102]}$ Behçet's Disease, ${ }^{[103]}$ arteriovenous malformations, ${ }^{[104]}$ sleep disturbances including obstructive sleep apnea syndrome (OSAS), ${ }^{[105,106]}$ extracranial venous hypertension secondary to cardiac septal defect, ${ }^{[107]}$ systemic lupus erythematosus, ${ }^{[108]}$ uremia, ${ }^{[109]}$ iron deficiency ane$\mathrm{mia}^{[110,111]}$ as well as some endocrine changes such as menstrual irregularities, use of oral contraceptives, hyperthyroidism and hypothyroidism. ${ }^{[12,113]}$

It has also been argued that an underlying thrombophilic defect in patients with IIH might play a role in the pathogenesis and some small studies showed abnormalities in prothrombotic factors. ${ }^{[14-116]}$ Theoretically, at least in some patients, IIH could be due to microthrombi impeding CSF drainage but not demonstrable on imaging. Therefore the role of thrombotic factors in IIH needs to be investigated by larger studies.

\section{Treatment options}

IIH does not currently have a well-established management algorithm, given the paucity of studies on the issue. ${ }^{[27]}$ CSF dynamics and homeostasis in IIH are complex and incompletely understood. Obese patients are encouraged to lose weight, and acetazolamide is the first choice of medical treatment. The primary goal is decreasing ICP to preserve visual function and to eliminate headache. In IIH patients who still have headache after resolution of ICP, preventive headache medications such as topiramate, which also has mild carbonic anhydrase activity, are used in clinical practice. ${ }^{[17]}$ The therapeutic role of repeated lumbar punctures which were popular in the past is now questioned due to its difficulties for the patient and lack of evidence showing its longlasting effects. Surgical options used in selected cases having visual loss include optic nerve sheath fenestration, CSF diversion procedures including either lumboperitoneal or ventriculoperitoneal shunting $^{[118]}$ in addition to the bariatric surgery for obe- 
sity ${ }^{[119]}$ and the newly introduced transverse sinus stenting as discussed above. ${ }^{[81,82,120]} \mathrm{IIH}$ is usually a self-limiting disease but shows relapses in some of the affected patients. ${ }^{[27]}$

\section{Conclusion}

The pathogenesis of IIH is still not fully understood. Multiple coexisting mechanisms including excessive CSF production, impaired CSF resorption, and obstructed venous outflow are likely to contribute to the pathogenesis. Increased weight clearly plays a role in the disease process, CSF pressure and the symptoms of IIH tend to fluctuate with spontaneous remissions (sometimes permanently), which are more supportive of an inflammatory process. BTSS may be a marker of increased ICP but whether it is the cause or the result of IIH remains still unsolved. Future studies are needed in order to optimize the biological understanding and reasonable treatment options of this intriguing disease.

\section{Conflict-of-interest issues regarding the author- ship or article: None declared.}

\section{Peer-rewiew: Externally peer-reviewed.}

\section{References}

1. Corbett JJ, Thompson HS. The rational management of idiopathic intracranial hypertension. Arch Neurol 1989;46(10):1049-51. CrossRef

2. Cigeroglu OB, Gokyigit A, Baykan-Kurt B, Çelik M, Oge AE. Pseudotumour cerebri: Review of 34 cases. (in Turkish). Archives of Neuropsychiatry 1994;31(1):57-62.

3. Friedman DI, Liu GT, Digre KB. Revised diagnostic criteria for the pseudotumor cerebri syndrome in adults and children. Neurology 2013;81(13):1159-65. CrossRef

4. Durcan FJ, Corbett JJ, Wall M. The incidence of pseudotumor cerebri. Population studies in lowa and Louisiana. Arch Neurol 1988;45(8):875-7. CrossRef

5. Radhakrishnan K, Thacker AK, Bohlaga NH, Maloo JC, Gerryo SE. Epidemiology of idiopathic intracranial hypertension: a prospective and case-control study. J Neurol Sci 1993;116(1):18-28. CrossRef

6. Radhakrishnan K, Ahlskog JE, Cross SA, Kurland LT, O'Fallon WM. Idiopathic intracranial hypertension (pseudotumor cerebri). Descriptive epidemiology in Rochester, Minn, 1976 to 1990. Arch Neurol 1993;50(1):78-80. CrossRef

7. Kesler A, Gadoth N. Epidemiology of idiopathic intracranial hypertension in Israel. J Neuroophthalmol 2001;21(1):12-4.

8. Phillips PH, Repka MX, Lambert SR. Pseudotumor cerebri in children. J AAPOS 1998;2(1):33-8. CrossRef

9. Wall $M$, George D. Idiopathic intracranial hypertension. A prospective study of 50 patients. Brain 1991;114 (Pt 1A):155-80.
10. Headache Classification Subcommittee of the International Headache Society. The International Classification of Headache Disorders: 2nd ed. Cephalalgia 2004;24(Suppl 1):9160.

11. Ekizoglu E, Baykan B, Orhan EK, Ertas M. The analysis of allodynia in patients with idiopathic intracranial hypertension. Cephalalgia 2012;32(14):1049-58. CrossRef

12. Bono F, Quattrone A. Idiopathic intracranial hypertension without papilloedema in headache sufferers. Cephalalgia 2009;29(5):594.

13. Marcelis J, Silberstein SD. Idiopathic intracranial hypertension without papilledema. Arch Neurol 1991;48(4):392-9.

14. Vieira DS, Masruha MR, Gonçalves AL, Zukerman E, Senne Soares CA, Naffah-Mazzacoratti Mda G, et al. Idiopathic intracranial hypertension with and without papilloedema in a consecutive series of patients with chronic migraine. Cephalalgia 2008;28(6):609-13. CrossRef

15. Mathew NT, Ravishankar K, Sanin LC. Coexistence of migraine and idiopathic intracranial hypertension without papilledema. Neurology 1996;46(5):1226-30. CrossRef

16. Digre KB, Nakamoto BK, Warner JE, Langeberg WJ, Baggaley SK, Katz BJ. A comparison of idiopathic intracranial hypertension with and without papilledema. Headache 2009;49(2):185-93. CrossRef

17. Bandyopadhyay S, Jacobson DM. Clinical features of lateonset pseudotumor cerebri fulfilling the modified dandy criteria. J Neuroophthalmol 2002;22(1):9-11. CrossRef

18. Bruce BB, Kedar S, Van Stavern GP, Corbett JJ, Newman NJ, Biousse V. Atypical idiopathic intracranial hypertension: normal BMI and older patients. Neurology 2010;74(22):182732. CrossRef

19. Zayit-Soudry S, Leibovitch I, Kesler A. Idiopathic intracranial hypertension after 40 years of age: clinical features in 23 patients. Eur J Ophthalmol 2008;18(6):989-93.

20. Bruce BB, Kedar S, Van Stavern GP, Monaghan D, Acierno $M D$, Braswell RA, et al. Idiopathic intracranial hypertension in men. Neurology 2009;72(4):304-9. CrossRef

21. Phillips PH. Pediatric pseudotumor cerebri. Int Ophthalmol Clin 2012 Summer;52(3):51-9. CrossRef

22. Kunte H, Schmidt F, Kronenberg G, Hoffmann J, Schmidt C, Harms $L$, et al. Olfactory dysfunction in patients with idiopathic intracranial hypertension. Neurology 2013;81(4):37982. CrossRef

23. Schmidt C, Wiener E, Hoffmann J, Klingebiel R, Schmidt $F$, Hofmann T, et al. Structural olfactory nerve changes in patients suffering from idiopathic intracranial hypertension. PLoS One 2012;7(4):e35221. CrossRef

24. Dandy WE. Intracranial pressure without brain tumor: diagnosis and treatment. Ann Surg 1937;106(4):492-513. CrossRef

25. Smith JL. Whence pseudotumor cerebri? J Clin Neuroophthalmol 1985;5(1):55-6.

26. Friedman DI, Jacobson DM. Diagnostic criteria for idiopathic intracranial hypertension. Neurology 2002;59(10):1492-5.

27. Skau M, Brennum J, Gjerris F, Jensen R. What is new about idiopathic intracranial hypertension? An updated review of mechanism and treatment. Cephalalgia 2006;26(4):384-99.

28. Sinclair AJ, Ball AK, Burdon MA, Clarke CE, Stewart PM, Curnow SJ, et al. Exploring the pathogenesis of IIH: an inflammatory perspective. J Neuroimmunol 2008;201-2:212-20. CrossRef

29. Sahs AJ, Joynt RJ. Brain swelling of unknown cause. Neurology 1956;6:791-803. CrossRef

30. Moser FG, Hilal SK, Abrams G, Bello JA, Schipper H, Silver AJ. 
MR imaging of pseudotumor cerebri. AJR Am J Roentgenol 1988;150(4):903-9. CrossRef

31. Gideon P, Sørensen PS, Thomsen C, Ståhlberg F, Gjerris F, Henriksen $O$. Increased brain water self-diffusion in patients with idiopathic intracranial hypertension. AJNR Am J Neuroradiol 1995;16(2):381-7.

32. Mathew NT, Meyer JS, Ott EO. Increased cerebral blood volume in benign intracranial hypertension. Neurology 1975;25(7):646-9. CrossRef

33. Raichle ME, Grubb RL Jr, Phelps ME, Gado MH, Caronna JJ. Cerebral hemodynamics and metabolism in pseudotumor cerebri. Ann Neurol 1978;4(2):104-11. CrossRef

34. Calabrese VP, Selhorst JB, Harbison JW. CSF infusion test in pseudotumor cerebri. Trans Am Neurol Assoc 1978;103:14650.

35. Janny P, Chazal J, Colnet G, Irthum B, Georget AM. Benign intracranial hypertension and disorders of CSF absorption. Surg Neurol 1981;15(3):168-74. CrossRef

36. Johnston I, Paterson A. Benign intracranial hypertension. II. CSF pressure and circulation. Brain 1974;97(2):301-12. CrossRef

37. Malm J, Kristensen B, Markgren P, Ekstedt J. CSF hydrodynamics in idiopathic intracranial hypertension: a long-term study. Neurology 1992;42(4):851-8. CrossRef

38. Daniels AB, Liu GT, Volpe NJ, Galetta SL, Moster ML, Newman NJ, et al. Profiles of obesity, weight gain, and quality of life in idiopathic intracranial hypertension (pseudotumor cerebri). Am J Ophthalmol 2007;143(4):635-41. CrossRef

39. Ko MW, Chang SC, Ridha MA, Ney JJ, Ali TF, Friedman DI, et al. Weight gain and recurrence in idiopathic intracranial hypertension: a case-control study. Neurology 2011;76(18):15647. CrossRef

40. Szewka AJ, Bruce BB, Newman NJ, Biousse V. Idiopathic intracranial hypertension: relation between obesity and visual outcomes. J Neuroophthalmol 2013;33(1):4-8. CrossRef

41. Johnson LN, Krohel GB, Madsen RW, March GA Jr. The role of weight loss and acetazolamide in the treatment of idiopathic intracranial hypertension (pseudotumor cerebri) Ophthalmology 1998;105(12):2313-7. CrossRef

42. Sugerman HJ, DeMaria EJ, Felton WL 3rd, Nakatsuka M, Sismanis $A$. Increased intra-abdominal pressure and cardiac filling pressures in obesity-associated pseudotumor cerebri. Neurology 1997;49(2):507-11. CrossRef

43. Lin J, Yan GT, Wang LH, Hao XH, Zhang K, Xue H. Leptin fluctuates in intestinal ischemia-reperfusion injury as inflammatory cytokine. Peptides 2004;25(12):2187-93. CrossRef

44. Lampl Y, Eshel Y, Kessler A, Fux A, Gilad R, Boaz M, et al. Serum leptin level in women with idiopathic intracranial hypertension. J Neurol Neurosurg Psychiatry 2002;72(5):6423. CrossRef

45. Ball AK, Sinclair AJ, Curnow SJ, Tomlinson JW, Burdon MA, Walker EA, et al. Elevated cerebrospinal fluid (CSF) leptin in idiopathic intracranial hypertension (IIH): evidence for hypothalamic leptin resistance? Clin Endocrinol (Oxf) 2009;70(6):863-9. CrossRef

46. Dhungana S, Sharrack B, Woodroofe N. Cytokines and chemokines in idiopathic intracranial hypertension. Headache 2009:49(2):282-5. CrossRef

47. Edwards LJ, Sharrack B, Ismail A, Tench CR, Gran B, Dhungana $S$, et al. Increased levels of interleukins 2 and 17 in the cerebrospinal fluid of patients with idiopathic intracranial hypertension. Am J Clin Exp Immunol 2013;2(3):234-44.

48. Wozniak SE, Gee LL, Wachtel MS, Frezza EE. Adipose tissue: the new endocrine organ? A review article. Dig Dis Sci
2009;54(9):1847-56. CrossRef

49. Tabassi A, Salmasi AH, Jalali M. Serum and CSF vitamin A concentrations in idiopathic intracranial hypertension. Neurology 2005;64(11):1893-6. CrossRef

50. Warner JE, Larson AJ, Bhosale P, Digre KB, Henley C, Alder $\mathrm{SC}$, et al. Retinol-binding protein and retinol analysis in cerebrospinal fluid and serum of patients with and without idiopathic intracranial hypertension. J Neuroophthalmol 2007;27(4):258-62. CrossRef

51. Cinciripini GS, Donahue S, Borchert MS. Idiopathic intracranial hypertension in prepubertal pediatric patients: characteristics, treatment, and outcome. Am J Ophthalmol 1999;127(2):178-82. CrossRef

52. Soelberg Sørensen P, Gjerris F, Svenstrup B. Endocrine studies in patients with pseudotumor cerebri. Estrogen levels in blood and cerebrospinal fluid. Arch Neurol 1986;43(9):9026. CrossRef

53. Toscano V, Sancesario G, Bianchi P, Cicardi C, Casilli D, Giacomini P. Cerebrospinal fluid estrone in pseudotumor cerebri: a change in cerebral steroid hormone metabolism? J Endocrinol Invest 1991;14(2):81-6. CrossRef

54. Glueck CJ, Aregawi D, Goldenberg N, Golnik KC, Sieve L, Wang P. Idiopathic intracranial hypertension, polycystic-ovary syndrome, and thrombophilia. J Lab Clin Med 2005;145(2):72-82. CrossRef

55. Glueck CJ, lyengar S, Goldenberg N, Smith LS, Wang P. Idiopathic intracranial hypertension: associations with coagulation disorders and polycystic-ovary syndrome. J Lab Clin Med 2003;142(1):35-45. CrossRef

56. Knochenhauer ES, Key TJ, Kahsar-Miller M, Waggoner W, Boots LR, Azziz R. Prevalence of the polycystic ovary syndrome in unselected black and white women of the southeastern United States: a prospective study. J Clin Endocrinol Metab 1998;83(9):3078-82. CrossRef

57. Kesler A, Kliper E, Shenkerman G, Stern N. Idiopathic intracranial hypertension is associated with lower body adiposity. Ophthalmology 2010;117(1):169-74. CrossRef

58. Skau M, Goetze JP, Rehfeld JF, Jensen R. Natriuretic propeptides in idiopathic intracranial hypertension. Regul Pept 2010;164(2-3):71-7. CrossRef

59. Johansson PA, Dziegielewska KM, Ek CJ, Habgood MD, Møllgård K, Potter A, et al. Aquaporin-1 in the choroid plexuses of developing mammalian brain. Cell Tissue Res 2005;322(3):353-64. CrossRef

60. Ameli PA, Madan M, Chigurupati S, Yu A, Chan SL, Pattisapu JV. Effect of acetazolamide on aquaporin-1 and fluid flow in cultured choroid plexus. Acta Neurochir Suppl 2012;113:5964. CrossRef

61. King LS, Nielsen S, Agre P. Aquaporin-1 water channel protein in lung: ontogeny, steroid-induced expression, and distribution in rat. J Clin Invest 1996;97(10):2183-91. CrossRef

62. Umenishi F, Schrier RW. Induction of human aquaporin-1 gene by retinoic acid in human erythroleukemia HEL cells. Biochem Biophys Res Commun 2002;293(3):913-7. CrossRef

63. Ma T, Jayaraman S, Wang KS, Song Y, Yang B, Li J, et al. Defective dietary fat processing in transgenic mice lacking aquaporin-1 water channels. Am J Physiol Cell Physiol 2001;280(1):C126-34

64. Bloch O, Manley GT. The role of aquaporin-4 in cerebral water transport and edema. Neurosurg Focus 2007;22(5):E3.

65. Auguste KI, Jin S, Uchida K, Yan D, Manley GT, Papadopoulos MC, Verkman AS. Greatly impaired migration of implanted aquaporin-4-deficient astroglial cells in mouse brain to- 
ward a site of injury. FASEB J 2007;21(1):108-16. CrossRef

66. Bloch O, Auguste KI, Manley GT, Verkman AS. Accelerated progression of kaolin-induced hydrocephalus in aquaporin-4-deficient mice. J Cereb Blood Flow Metab 2006;26(12):1527-37. CrossRef

67. Waters P, Jarius S, Littleton E, Leite MI, Jacob S, Gray B, et al. Aquaporin-4 antibodies in neuromyelitis optica and longitudinally extensive transverse myelitis. Arch Neurol 2008;65(7):913-9. CrossRef

68. Dhungana $S$, Waters $P$, Ismail $A$, Woodroofe $N$, Vincent A, Sharrack B. Absence of aquaporin-4 antibodies in patients with idiopathic intracranial hypertension. J Neurol 2010;257(7):1211-2. CrossRef

69. Ekizoglu E, Içoz S, Tuzun E, Birisik O, Kocasoy-Orhan E, Akman-Demir G, et al. Aquaporin-4 antibodies are not present in patients with idiopathic intracranial hypertension. Cephalalgia 2012;32(3):198-202. CrossRef

70. Riggeal BD, Bruce BB, Saindane AM, Ridha MA, Kelly LP, Newman NJ, et al. Clinical course of idiopathic intracranial hypertension with transverse sinus stenosis. Neurology 2013;80(3):289-95. CrossRef

71. Farb RI, Vanek I, Scott JN, Mikulis DJ, Willinsky RA, Tomlinson $\mathrm{G}$, et al. Idiopathic intracranial hypertension: the prevalence and morphology of sinovenous stenosis. Neurology 2003;60(9):1418-24. CrossRef

72. Bono F, Messina D, Giliberto C, Cristiano D, Broussard G, D'Asero $S$, et al. Bilateral transverse sinus stenosis and idiopathic intracranial hypertension without papilledema in chronic tension-type headache. J Neurol 2008;255(6):80712. CrossRef

73. Bono F, Messina D, Giliberto C, Cristiano D, Broussard G, Fera $F$, et al. Bilateral transverse sinus stenosis predicts IIH without papilledema in patients with migraine. Neurology 2006;67(3):419-23. CrossRef

74. McGeeney BE, Friedman DI. Pseudotumor cerebri pathophysiology. Headache 2014 Jan 16. CrossRef

75. King JO, Mitchell PJ, Thomson KR, Tress BM. Manometry combined with cervical puncture in idiopathic intracranial hypertension. Neurology 2002;58(1):26-30. CrossRef

76. Stevens SA, Previte M, Lakin WD, Thakore NJ, Penar PL, Hamschin B. Idiopathic intracranial hypertension and transverse sinus stenosis: a modelling study. Math Med Biol 2007;24(1):85-109. CrossRef

77. Leach JL, Jones BV, Tomsick TA, Stewart CA, Balko MG. Normal appearance of arachnoid granulations on contrast-enhanced CT and MR of the brain: differentiation from dural sinus disease. AJNR Am J Neuroradiol 1996;17(8):1523-32.

78. Strydom MA, Briers N, Bosman MC, Steyn S. The anatomical basis of venographic filling defects of the transverse sinus. Clin Anat 2010;23(2):153-9.

79. Puffer RC, Mustafa W, Lanzino G. Venous sinus stenting for idiopathic intracranial hypertension: a review of the literature. J Neurointerv Surg 2013;5(5):483-6. CrossRef

80. Ahmed RM, Wilkinson M, Parker GD, Thurtell MJ, Macdonald J, McCluskey PJ, et al. Transverse sinus stenting for idiopathic intracranial hypertension: a review of 52 patients and of model predictions. AJNR Am J Neuroradiol 2011;32(8):140814. CrossRef

81. Donnet $A$, Metellus $P$, Levrier O, Mekkaoui $C$, Fuentes $S$, Dufour $\mathrm{H}$, et al. Endovascular treatment of idiopathic intracranial hypertension: clinical and radiologic outcome of 10 consecutive patients. Neurology 2008;70(8):641-7. CrossRef

82. Kumpe DA, Bennett JL, Seinfeld J, Pelak VS, Chawla A, Tier- ney M. Dural sinus stent placement for idiopathic intracranial hypertension. J Neurosurg 2012;116(3):538-48. CrossRef

83. Radvany MG, Solomon D, Nijjar S, Subramanian PS, Miller NR, Rigamonti $D$, et al. Visual and neurological outcomes following endovascular stenting for pseudotumor cerebri associated with transverse sinus stenosis. J Neuroophthalmol 2013;33(2):117-22. CrossRef

84. Rohr A, Dörner L, Stingele R, Buhl R, Alfke K, Jansen O. Reversibility of venous sinus obstruction in idiopathic intracranial hypertension. AJNR Am J Neuroradiol 2007;28(4):656-9.

85. Rohr A, Bindeballe J, Riedel C, van Baalen A, Bartsch T, Doerner $\mathrm{L}$, Jansen $\mathrm{O}$. The entire dural sinus tree is compressed in patients with idiopathic intracranial hypertension: a longitudinal, volumetric magnetic resonance imaging study. Neuroradiology 2012;54:25-33. CrossRef

86. De Simone R, Marano E, Fiorillo C, Briganti F, Di Salle F, Volpe $A$, et al. Sudden re-opening of collapsed transverse sinuses and longstanding clinical remission after a single lumbar puncture in a case of idiopathic intracranial hypertension. Pathogenetic implications. Neurol Sci 2005;25(6):342-4.

87. Lee SW, Gates P, Morris P, Whan A, Riddington L. Idiopathic intracranial hypertension; immediate resolution of venous sinus "obstruction" after reducing cerebrospinal fluid pressure to $<10 \mathrm{cmH}(2)$ O. J Clin Neurosci 2009;16(12):1690-2.

88. Bateman GA. Stenoses in idiopathic intracranial hypertension: to stent or not to stent? AJNR Am J Neuroradiol 2008;29(2):216. CrossRef

89. Bateman GA, Stevens SA, Stimpson J. A mathematical model of idiopathic intracranial hypertension incorporating increased arterial inflow and variable venous outflow collapsibility. J Neurosurg 2009;110(3):446-56. CrossRef

90. De Simone R, Ranieri A, Bonavita V. Advancement in idiopathic intracranial hypertension pathogenesis: focus on sinus venous stenosis. Neurol Sci 2010;31 Suppl 1:S33-9.

91. Subramanian PS, Haq A. Cerebral venous sinus thrombosis and stenosis in pseudotumor cerebri syndrome. Int Ophthalmol Clin 2014;54(1):61-71. CrossRef

92. Bono F, Lupo MR, Lavano A, Mangone L, Fera F, Pardatscher $\mathrm{K}$, et al. Cerebral MR venography of transverse sinuses in subjects with normal CSF pressure. Neurology 2003;61(9):126770. CrossRef

93. Bono F, Giliberto C, Mastrandrea C, Cristiano D, Lavano A, Fera F, et al. Transverse sinus stenoses persist after normalization of the CSF pressure in IIH. Neurology 2005;65(7):10903. CrossRef

94. Karahalios DG, Rekate HL, Khayata MH, Apostolides PJ. Elevated intracranial venous pressure as a universal mechanism in pseudotumor cerebri of varying etiologies. Neurology 1996;46(1):198-202. CrossRef

95. Agarwal $\mathrm{P}$, Kumar $\mathrm{M}$, Arora V. Clinical profile of cerebral venous sinus thrombosis and the role of imaging in its diagnosis in patients with presumed idiopathic intracranial hypertension. Indian J Ophthalmol 2010;58(2):153-5. CrossRef

96. Bond DW, Charlton CP, Gregson RM. Drug points: Benign intracranial hypertension secondary to nasal fluticasone propionate. BMJ 2001;322(7291):897. CrossRef

97. Crock PA, McKenzie JD, Nicoll AM, Howard NJ, Cutfield W, Shield LK, et al. Benign intracranial hypertension and recombinant growth hormone therapy in Australia and New Zealand. Acta Paediatr 1998;87(4):381-6. CrossRef

98. Feldman $\mathrm{MH}$, Schlezinger NS. Benign intracranial hypertension associated with hypervitaminosis A. Arch Neurol 1970;22(1):1-7. CrossRef 
99. Gardner K, Cox T, Digre KB. Idiopathic intracranial hypertension associated with tetracycline use in fraternal twins: case reports and review. Neurology 1995;45(1):6-10. CrossRef

100. Malozowski S, Tanner LA, Wysowski DK, Fleming GA, Stadel BV. Benign intracranial hypertension in children with growth hormone deficiency treated with growth hormone. J Pediatr 1995;126(6):996-9. CrossRef

101. Weese-Mayer DE, Yang RJ, Mayer JR, Zaparackas Z. Minocycline and Pseudotumor cerebri: The well-known but wellkept secret. Pediatrics 2001;108(2):519-20. CrossRef

102. Sevgi E, Yalcin G, Kansu T, Varli K. Drug induced intracranial hypertension associated with sulphasalazine treatment. Headache 2008;48(2):296-8. CrossRef

103. Akman-Demir G, Bahar S, Baykan-Kurt B, Gürvit iH, Serdaroğlu P. Intracranial hypertension in Behçet's disease. Eur J Neurol 1996;3(1):66-70. CrossRef

104. Silberstein P, Kottos P, Worner C, Glenn D, Shnier R, Davies $M$, et al. Dural arteriovenous fistulae causing pseudotumour cerebri syndrome in an elderly man. J Clin Neurosci 2003;10(2):242-3. CrossRef

105. Lee AG, Golnik K, Kardon R, Wall M, Eggenberger E, Yedavally $S$. Sleep apnea and intracranial hypertension in men. Ophthalmology 2002;109(3):482-5. CrossRef

106. Marcus DM, Lynn J, Miller JJ, Chaudhary O, Thomas D, Chaudhary B. Sleep disorders: a risk factor for pseudotumor cerebri? J Neuroophthalmol 2001;21(2):121-3. CrossRef

107. Jicha GA, Suarez GA. Pseudotumor cerebri reversed by cardiac septal defect repair. Neurology 2003;60(12):2016-7.

108. Green L, Vinker S, Amital H, Amir T, Bar-Dayan Y, Levi Y, et al. Pseudotumor cerebri in systemic lupus erythematosus. Semin Arthritis Rheum 1995;25(2):103-8. CrossRef

109. Guy J, Johnston PK, Corbett JJ, Day AL, Glaser JS. Treatment of visual loss in pseudotumor cerebri associated with uremia. Neurology 1990;40(1):28-32. CrossRef

110. Tugal O, Jacobson R, Berezin S, Foreman S, Berezin S, Brudnicki $A$, et al. Recurrent benign intracranial hypertension due to iron deficiency anemia. Case report and review of the literature. Am J Pediatr Hematol Oncol 1994;16(3):26670. CrossRef

111. Forman EB, O'Byrne JJ, Capra L, McElnea E, King MD. Idiopathic intracranial hypertension associated with iron-deficiency anaemia. Arch Dis Child 2013;98(6):418. CrossRef

112. Dickman MS, Somasundaram M, Brzozowski L. Pseudotumor cerebri and hyperthyroidism. NY State J Med 1980;80(7 Pt 1):1118-20.

113. Press OW, Ladenson PW. Pseudotumor cerebri and hypothyroidism. Arch Intern Med 1983;143(1):167-8. CrossRef

114. Backhouse $O$, Metcalfe T, Goulding P, McEvoy M, Menage M. Factor $V$ Leiden mutation in association with idiopathic intracranial hypertension. Br J Ophthalmol 1998;82(7):844.

115. Glueck CJ, Goldenberg N, Golnik K, Sieve L, Wang P. Idiopathic intracranial hypertension: associations with thrombophilia and hypofibrinolysis in men. Clin Appl Thromb Hemost 2005;11(4):441-8. CrossRef

116. Sussman J, Leach M, Greaves M, Malia R, Davies-Jones GA. Potentially prothrombotic abnormalities of coagulation in benign intracranial hypertension. J Neurol Neurosurg Psychiatry 1997;62(3):229-33. CrossRef

117. Celebisoy N, Gökçay F, Sirin H, Akyürekli O. Treatment of idiopathic intracranial hypertension: topiramate vs acetazolamide, an open-label study. Acta Neurol Scand 2007;116(5):322-7. CrossRef

118. Sinclair AJ, Kuruvath S, Sen D, Nightingale PG, Burdon MA, Flint $G$. Is cerebrospinal fluid shunting in idiopathic intracranial hypertension worthwhile? A 10-year review. Cephalalgia 2011;31(16):1627-33. CrossRef

119. Spitze A, Malik A, Lee AG. Surgical and endovascular interventions in idiopathic intracranial hypertension. Curr Opin Neurol 2014;27(1):69-74. CrossRef

120. Ahmed R, Friedman DI, Halmagyi GM. Stenting of the transverse sinuses in idiopathic intracranial hypertension. J Neuroophthalmol 2011;31(4):374-80. CrossRef 